Available online at http://www.anpad.org.br/bar

BAR, Curitiba, v.8, n.1, art. 2, pp. 21-36, Jan./Mar.

\title{
International Relations and the Paradiplomacy of Brazilian Cities: Crafting the Concept of Local International Management
}

Carlos R. S. Milani *

E-mail address: crsmilani@gmail.com Universidade Federal do Estado do Rio de Janeiro - UNIRIO and Universidade do Grande Rio - UNIGRANRIO Rio de Janeiro, RJ, Brazil.

Maria Clotilde Meirelles Ribeiro E-mail address: clotilde.ribeiro@univasf.edu.br Fundação Universidade Federal do Vale do São Francisco - UNIVASF Petrolina, PE, Brazil.

* Corresponding author: Carlos R. S. Milani

Avenida Ataulfo de Paiva, 50/1301, Bloco I-A, Leblon, Rio de Janeiro/RJ, 22440-033.

Copyright (C) 2011 Brazilian Administration Review. All rights reserved, including rights for translation. Parts of this work may be quoted without prior knowledge on the condition that the source is identified. 


\begin{abstract}
Based on the broader context of globalization as politics, this paper adopts the following assumption: cities through their transnational cooperation networks and economic projects are the expression of a new political actor that has shifted its scale of operations, and have thus partly emancipated themselves from the monopoly of the nation-state in the deployment of transborder public action. In pursuance of developing this assumption, this paper approaches the discussion on municipal paradiplomacy in three parts: firstly, it presents the historical and theoretical background of paradiplomacy in Brazil; secondly, it looks into the empirical reality of several Brazilian municipalities and their international actions; thirdly, it presents a series of critical questions for analyzing cities and their transnational networks as new political actors in the global arena. Empirically, this paper raises key issues related to the multiple ways in which municipalities throughout Brazil develop transnational activities, whereas analytically it aims to provide a better understanding of their soft-border approach, as well as their pragmatic association between a renewed identity in the global scenario and an innovative strategy of local international management.
\end{abstract}

Key words: globalization and sovereignty; internationalization of cities; municipal paradiplomacy; local international management; Brazilian municipalities. 


\section{Introduction}

Globalization is not merely a competition for market shares and well-timed economic growth initiatives; neither is it just a matter of trade opportunities and liberalization. Globalization has also evolved into a social and political struggle for defining cultural values and political identities (Benhabib, 2006; Milani \& Laniado, 2007), having major consequences for the internationalization of politics through the increasing development of transnational actors, networks and institutions (Ianni, 2002; Santos, Souza, Scarlato, \& Arroyo, 1994). Subnational entities, such as provinces, federatestates and municipalities also benefit from various political opportunity structures that have emerged from globalization processes.

This means that in a broader context of globalization as politics (Baylis \& Smith, 2001; Beck, 2003; Dollfus, 1997; Fiori, 2005; Smouts, 2004), the nation-state no longer has the same exclusive and traditional role it used to have in international relations; non-state economic actors, social movements and subnational governments, inter alia, have gradually come to have an important say in global affairs. The political context within globalization opens unprecedented breaches in power equations among states, markets and civil societies (Therborn, 2000; Touraine, 2005; Velasco \& Cruz, 2004). Globalization defines new modalities in the management of internationalization processes being deployed by states, business, social players and also subnational political entities. Along with the globalization phenomenon, there come not only a series of violations of national borders by flows of technology, economy, culture and information, but also several trespassing actions by infra-national political players and their regional and global networks or organizations. At the same time, transnational problems of major relevance to the system-wide functioning of the world (such as financial crises, cross-border environmental degradation, forced migration, drug trafficking, the spread of genetically-modified organisms, civic alliances for human rights, etc.) transcend the responsibility of the single nation-state and represent a major challenge that can hardly be dealt with solely within the framework of intergovernmental relations.

As a result, there is a profound redefinition of the political field of international management, both in the configuration of its context and in the way it evolves as experience, method and practice (the action). It is no longer possible to understand the political field of international management simply as a discrete set of governing institutions, strategies and policies, including players such as states, multinational corporations, international agreements and intergovernmental organizations. In an intellectual exercise of theoretical cross-fertilization, the traditions of International Management and International Relations must take into account the experience of subnational political entities in order to foster a renewal of concepts and analytical frames.

As an attempt to contribute to such an endeavor, this paper adopts the following assumption: cities through their transnational cooperation networks and economic projects are the expression of a new political actor that has shifted its scale of operations, and have thus partly emancipated themselves from the monopoly of the nation-state in the deployment of transborder public action (Salomón, 2007; Sassen, 2006). As the world's population have become increasingly urban and complex globalization-fragmentation processes have advanced, cities have challenged the Westphalian imaginary and the exclusive role of the nation-state as the bounded political community with the capacity to frame and control a fixed and vertical national territory. In pursuance of developing this assumption, this paper approaches the discussion on municipal paradiplomacy in three parts: firstly, it presents the historical and theoretical background of paradiplomacy in Brazil; secondly, it looks into the empirical reality of several Brazilian municipalities and their international actions; thirdly, it presents a series of key questions for analyzing cities and their transnational networks as new political actors in the global arena. Empirically the authors of this paper intend to analyze the multiple ways through which municipalities across Brazil develop paradiplomatic activities, but also to better understand their "soft-border approach", the economic strategies that they deploy, and whether or not they build a political identity, thus questioning unconditioned national sovereignty as a fundamental tenet of the international system. Theoretically this paper crafts the concept of local international 
management, herein defined as a series of organizational structures and management procedures that guarantee an increasing capacity for cities to set up, participate in, and foster regional and global economic, cultural, social and information networks or flows.

\section{Major Trends in Paradiplomacy in Brazil: Historical and Theoretical Background}

Since diplomacy is a term that naturally corresponds to the organized political exercise of the nation-state's series of international actions, paradiplomacy has been used in recent Brazilian International Relations literature to express the ensemble of international actions of non-state actors: private paradiplomacy, non-governmental paradiplomacy, but also federate-states and municipal paradiplomacy (Associação Brasileira de Organizações Não-Governamentais [Abong], 2007; Troyjo, 2005; Vigevani, 2006). In spite of the fact that the conceptual validity of this notion has frequently been called into question, paradiplomacy can be simply defined as subnational governments' involvement in international relations through the establishment of formal and informal ties, be they permanent or ad hoc, with foreign public or private entities, with the objective of promoting social, economic, cultural or political dimensions of development (Cornago, 2010).

The phenomenon has grown both quantitatively and qualitatively since the early nineties in Brazil, thanks to structural changes in the world order and domestic political and economic transformations. The end of the Cold War and all its associated features (increased development of non-state actors; new metrics of territory, diversified political identities, globalization of diversified sorts of flows and sweeping transformation of a state-centric political order) coincided with the implementation of new external and internal patterns of economic integration, the re-democratization of the Brazilian political and civil society, as well as the promulgation of the new 1988 Constitution.

In such a context, as Ribeiro (2008) reports, paradiplomacy of subnational entities in Brazil has significantly developed since the late 1980s thanks to the decentralization architecture of the Brazilian federation approved in the new constitutional system. It is true that subnational entities have also had their paradiplomatic activities activated and facilitated in other federative systems, such as in the USA, Germany, Belgium, Argentina or Mexico. It has also been the case of particular historical processes of state building where subnational entities must be politically and culturally acknowledged, as in the case of Spain (Cornago, 2010) or Canada (Lachapelle \& Paquin, 2005). National constitutional contexts and political paths matter in the building of explanatory hypotheses to understand the role of subnational governments in the deployment of their paradiplomatic activities.

In the case of the Brazilian constitutional system, there is no legal mention about the legitimacy of international actions undertaken by subnational entities (Rodrigues, 2004). Municipalities and federate-states are given a series of complementary and exclusive responsibilities, and no constitutional statement forbids them from developing international activities. Article 21 states that it falls to the Union (i.e., the federal State) to maintain relations with other States and participate in international organizations. In this light, a proposal for a constitutional amendment is currently under discussion within the Brazilian National Congress (project 475/2005, known as PEC da paradiplomacia). According to this proposal, federate-states, the Federal District (Brasilia) and municipalities would count on constitutional support in the development of their international strategies and agreements of technical cooperation with their international partners.

Irrespective of this constitutional gap, many federate-states and municipalities have been extremely active internationally. Even some national associations such as the National Confederation of Municipalities (Confederação Nacional de Municípios [CNM]) and the National Front of Mayors (Frente Nacional de Prefeitos) recognize and steer the international action of Brazilian cities; they organize seminars, training courses, and publish guides for the development of international projects. This also applies to the regional network of cities Mercociudades, created in $1995^{(1)}$, and the Brazilian Forum of International Relations municipal secretaries, launched in 2005. 
At the federal level, the Ministry of External Relations (known in Brazil as Itamaraty) established a special administrative service for dealing with municipalities and federate-states in 2003 (the Assessoria de Relações Federativas [ARF]). Directly under the authority of the Minister of Foreign Affairs, this service was then transformed into the Council of Federative and Parliamentary Issues (AFEPA). This service aims to "create a dialog between the Ministry and governments of federate-states and municipalities, thus giving more capillarity to the formulation process of foreign policy” (Rodrigues, 2004, p. 25). Itamaraty has also set up regional offices or local antennas in various federate-states.

\section{Brazilian Municipal Paradiplomacy: Research Design and Empirical Analysis}

How have Brazilian municipalities been developing their strategies of international action since the early 1990s? This was our central research question in the empirical analysis of municipal paradiplomacy in Brazil in 2007/2008. Municipalities have been selected based on seven criteria, each one corresponding to a hypothesis to examine why Brazilian municipalities should go international (see Table 1).

Table 1

\section{Criteria for Selecting Municipalities in the Survey}

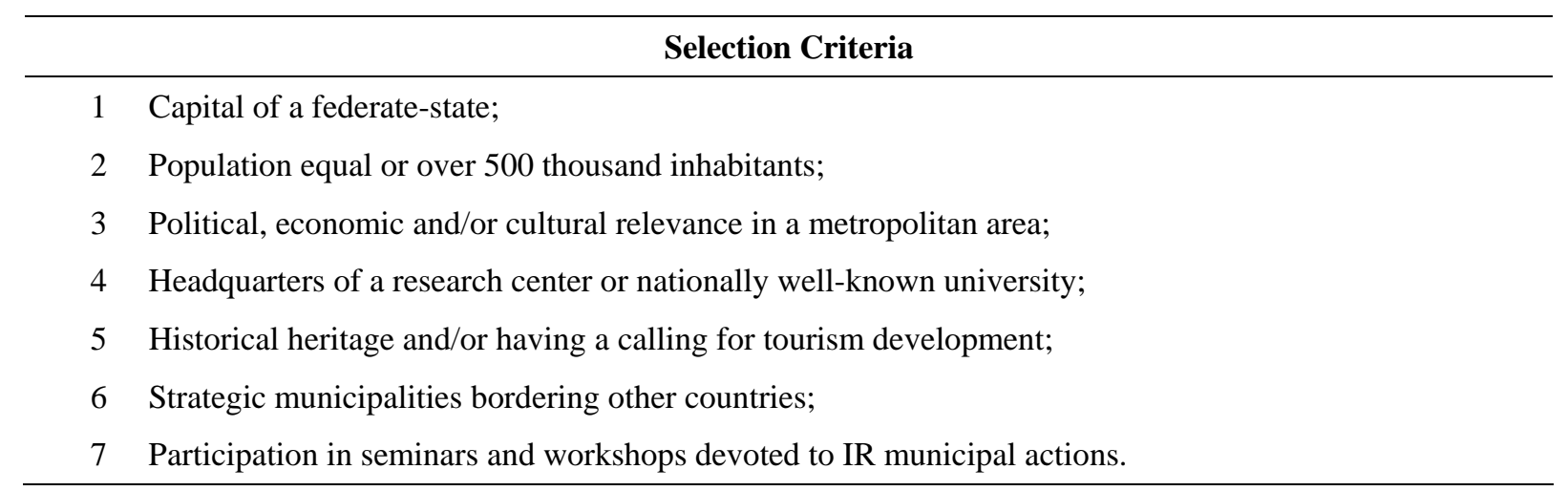

Based on these seven criteria, seventy-two municipalities were selected, twenty of them situated in the North and North-East of Brazil (less developed socioeconomically), and another fifty-two in the South, Southeast and Central West (more developed). In this survey, municipalities were not required to fit all seven criteria in order to be part of the research sample; only one of them was enough for the selection of a municipality, even though some cities fit into two or more criteria at the same time. In order to build the sample, we included every capital, and examined all Brazilian municipalities that have at least five hundred thousand inhabitants, according to online databases of the Brazilian Institute of Geography and Statistics (IBGE). We then followed the list of criteria, without giving any specific weight to each of them in our analysis (see Figures 1 and 2). 


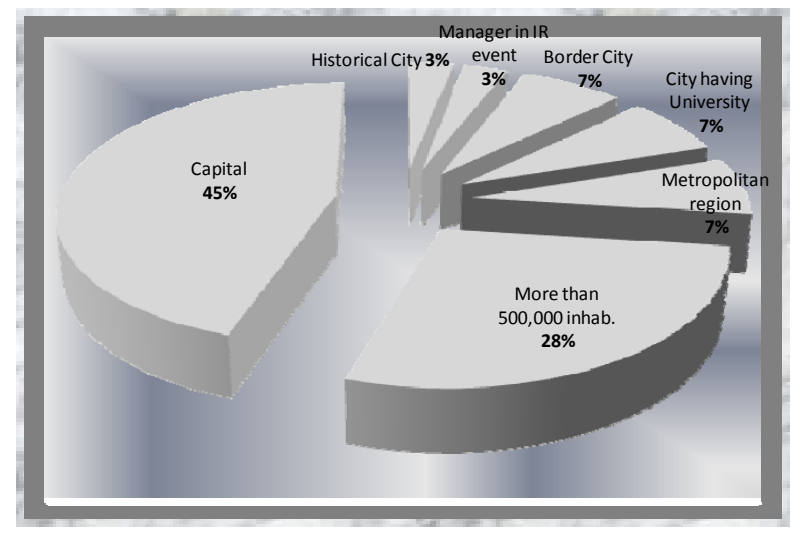

Figure 1. Number of Selected Municipalities and Criteria.

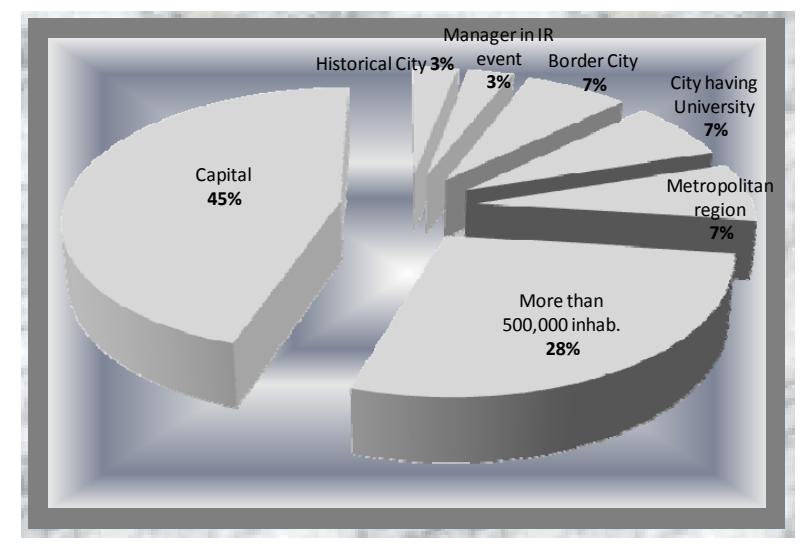

Figure 2. Total of 72 Surveyed Municipalities (see endnote 2).

Figure 2 shows three different categories of cities as far as their international activities are concerned: surveyed cities that do not develop any paradiplomatic activities; cities that develop their paradiplomacy having a formal international relations structure; and cities that develop their paradiplomacy without having set up any formal structure. It is necessary to note that in this survey a formal international relations (IR) structure corresponds to the creation of one of the following institutions at the local level: a municipal secretariat in charge of international affairs, an administrative service under a secretariat, or the nomination of a team under a coordinator. Municipalities have the autonomy to choose their own particular type of administrative service that will be locally responsible for international affairs, and may call it a municipal secretariat, an office within a secretariat or a council.

All seventy-two municipalities responded to the questionnaire ${ }^{(2)}$. Tables 2 and 3 present the seventy-two municipalities that were surveyed, among which 51 (70.8 per cent) exercise some form of paradiplomatic activity; however, only 29 of them (40.2 per cent) have already set up a local organizational structure which is responsible for the management of the city's international relations.

Moreover, Tables 2 and 3 confirm that the richest regions in the country also concentrate the majority of municipalities developing paradiplomatic activities. The South and Southeast regions correspond to almost $76 \%$ of the total of 51 municipalities. As stated by Rodrigues (2004), Nunes (2005) and Salomón (2007), this survey confirms that Sao Paulo, Rio de Janeiro and Porto Alegre are emblematic examples of municipal paradiplomacy in Brazil. 
Table 2

\section{Municipalities with a Particular IR Structure}

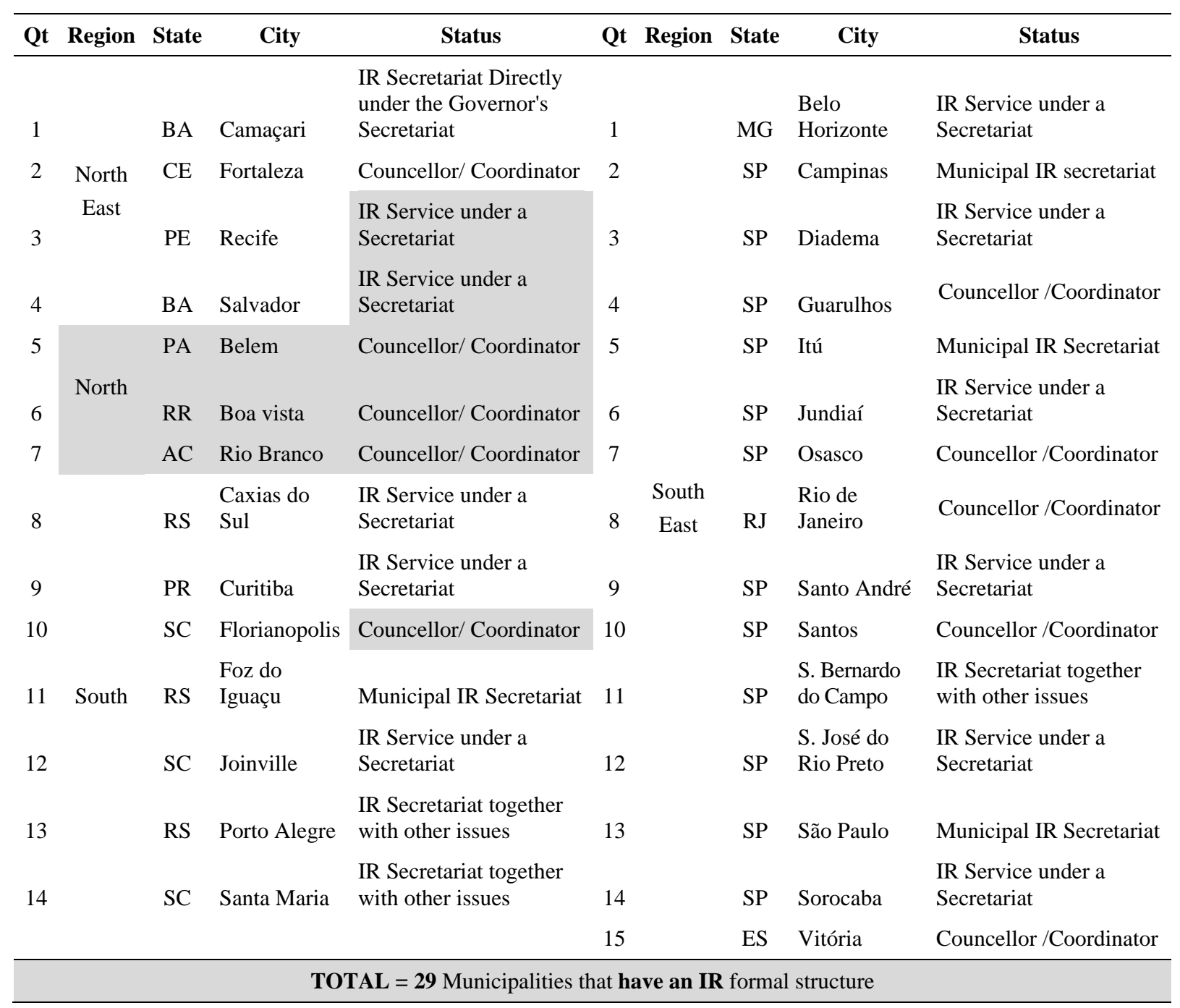


Table 3

Municipalities WITHOUT Local IR Structures

\begin{tabular}{|c|c|c|c|c|c|c|c|}
\hline \multicolumn{4}{|c|}{ Not developing paradiplomacy } & \multicolumn{4}{|c|}{ Developing paradiplomacy } \\
\hline Qt & Region & State & City & Qt & Region & State & City \\
\hline 1 & \multirow{5}{*}{$\mathrm{CO}$} & GO & Goiânia & 1 & \multirow{2}{*}{$\mathrm{CO}$} & MS & Corumbá \\
\hline 2 & & MS & Campo Grande & 2 & & MT & Cuiabá \\
\hline 3 & & MS & Ponta-Porã & 3 & \multirow{7}{*}{$\mathrm{NE}$} & BA & Feira de Santana \\
\hline 4 & & TO & Palmas & 4 & & MA & São Luis \\
\hline 5 & & AL & Maceió & 5 & & PB & Campina Grande \\
\hline 6 & $\mathrm{NE}$ & $\mathrm{PE}$ & Jaboatão dos Guararapes & 6 & & $\mathrm{~PB}$ & João Pessoa \\
\hline 7 & \multirow{3}{*}{ NO } & $\mathrm{SE}$ & Aracaju & 7 & & $\mathrm{PE}$ & Olinda \\
\hline 8 & & RO & Porto Velho & 8 & & PI & Teresina \\
\hline 9 & & MG & Contagem & 9 & & $\mathrm{RN}$ & Natal \\
\hline 10 & \multirow{4}{*}{$\mathrm{SE}$} & MG & Rio Preto & 10 & \multirow{2}{*}{ NO } & $\mathrm{AM}$ & Manaus \\
\hline 11 & & $\mathrm{RJ}$ & Duque de Caxias & 11 & & AP & Macapá \\
\hline 12 & & RJ & Nova Iguaçu & 12 & \multirow{8}{*}{ SE } & MG & Ipatinga \\
\hline 13 & & SP & Americana & 13 & & MG & Ouro Preto \\
\hline 14 & \multirow{9}{*}{ SU } & SP & São José dos Campos & 14 & & MG & Uberlândia \\
\hline 15 & & PR & Londrina & 15 & & RJ & São Gonçalo \\
\hline 16 & & RS & Chuí & 16 & & SP & Cubatão \\
\hline 17 & & RS & Itaqui & 17 & & SP & Jacareí \\
\hline 18 & & RS & Jaguarão & 18 & & SP & Ribeirao Preto \\
\hline 19 & & RS & São Borja & 19 & & SP & São Caetano do Sul \\
\hline 20 & & RS & Uruguaiana & 20 & & PR & Maringá \\
\hline \multirow[t]{2}{*}{21} & & SC & Blumenau & 21 & SU & RS & Gravataí \\
\hline & & & & 22 & & RS & Santana do Livramento \\
\hline \multicolumn{4}{|c|}{ Total = 21 municipalities that don't develop paradiplomacy } & \multicolumn{4}{|c|}{ Total = 22 municipalities that develop paradiplomacy } \\
\hline
\end{tabular}

In short, of the seventy-two surveyed cities: (a) twenty-two develop paradiplomatic activities, but have not set up formal IR structures locally; (b) twenty-nine have a formal IR organization; (c) and twenty-one do not implement paradiplomatic activities. If we focus on the first group, we may find many informal and not well-known projects which are less visible and transparent, and most of them are located in the North-East of Brazil (a region that is comparatively less developed). They all use a much diversified series of paradiplomatic activities confirming previous studies undertaken in other contexts by Soldatos (1990), Duchacek (1990) and Paquin (2004), such as international missions, participation in fairs and international events, technical cooperation schemes, exchange of best practices, and agreements setting up twin cities. One case that deserves to be mentioned is Macapá (capital of the federate-state of Amapa), which signed a series of bilateral cooperation projects with Cayenne in French Guiana in 1990. Another two cities that should be mentioned are Uberlandia and Olinda, for their relationships with the American Chamber of Commerce and UNESCO's cultural programs, respectively. The main countries having established partnerships with these twenty-two municipalities are France, Spain, Portugal and Italy, but also China and Japan. 


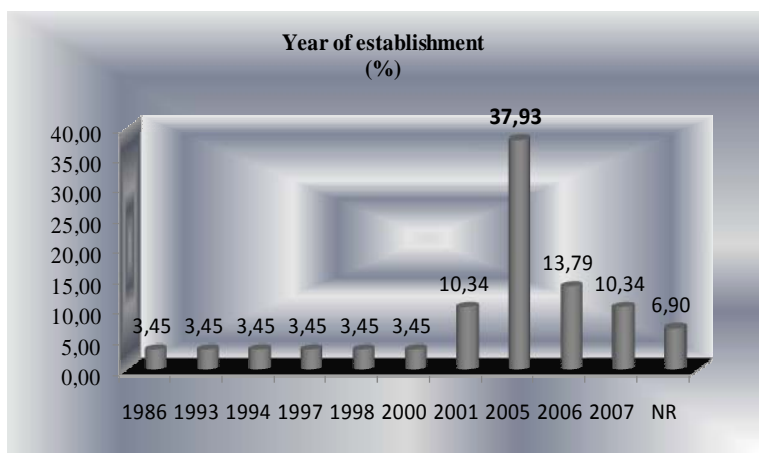

Figure 3. Establishment of a formal municipal organization to deal with international affairs (29 municipalities).

Concerning the second group of municipalities having set up a formal structure to deal with international affairs, our research shows that the majority of them were created between 2004 and 2007 (Figure 3). Domestically, this boom can be explained by the transition from President FHC to President Lula, and the transfer of old internationalization practices from municipalities governed by the Partido dos Trabalhadores to the federal level, thus contributing to the construction of a strategy of what we define in this paper as local international management. Indeed, between 2003 and 2004, the new federal government established a series of services within Itamaraty and the President's Secretariat (Secretária da Presidência da República) in order to deal with municipalities, federate-states and their paradiplomatic activities, particularly within the Mercosur integration process. Many municipalities also confirm that the creation of a formal structure gives visibility to the city nationally and abroad, an important factor for attracting technical assistance, investments and trade (see Figure 4).

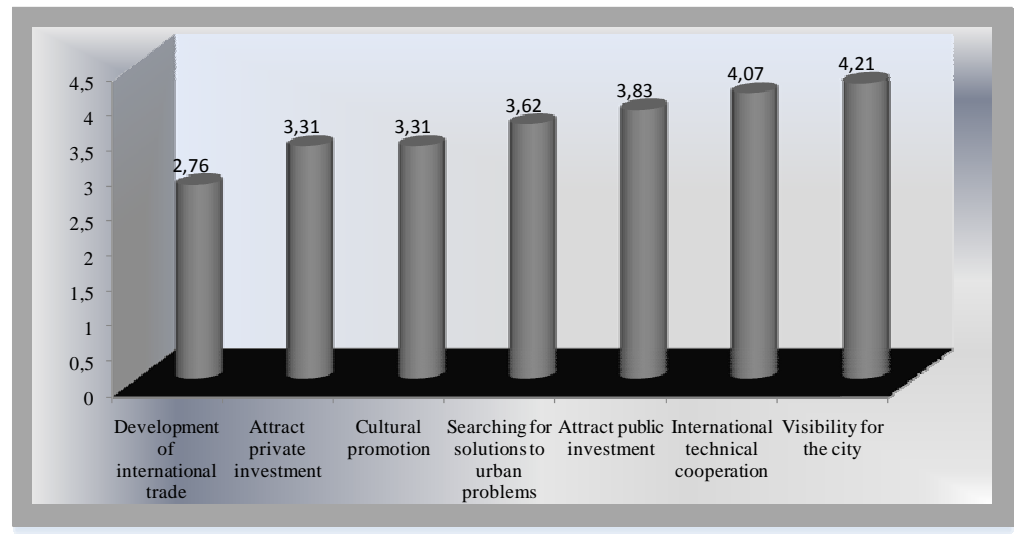

Figure 4. Why have you set up a formal structure? (29 respondents).

Another important feature to be discussed is the political articulation between the federal government and local government, which seems to pose a problem since almost $66 \%$ of the surveyed municipalities indicate that there are scarce opportunities for institutional dialog and coherencebuilding. Similar concerns were voiced by $86 \%$ of the surveyed municipalities concerning their relationship with federate-state representatives. Our research also shows that one fourth of surveyed municipalities deploy their international strategies in an isolated fashion, without strategic planning and focus, which implies the absence of an articulated and strategic project in the long term. Nevertheless, the same amount of municipalities (but not necessarily the same ones) are planning their international affairs strategically, in collaboration with other municipal administrative services and secretariats.

Therefore, the internationalization of Brazilian cities and their diplomatic efforts require more careful political monitoring by federal government institutions, as well as the diplomatic system. The deployment of sustainable paradiplomacy should result in the establishment of more intense and 
frequent channels of consultation and coordination between local, regional and national officials. Obviously, this necessitates some level of political acceptance on the part of State officials. Assuming that there is such basic acceptance, the intensity of the consultation and coordination will depend first and foremost on the nature and extent of municipal paradiplomacy. As Lecours (2008) asserts, if the foreign action of a subnational unit is modest, a fairly informal process of information-sharing may very well be enough to place state officials at ease; if paradiplomacy is more ambitious, the relationship needs to go beyond information-sharing to include genuine consultation and even coordination (Lecours, 2008, p. 8).

In Figure 5 we can see that municipalities with a formal structure develop three main paradiplomatic actions: participation in transnational networks (such as Mercociudades), participation in international conferences and events (city fairs, for instance), twin-city agreements, city marketing, membership of international associations and regional and global networking. Table 4 shows main cities that have signed twin-city agreements with these surveyed Brazilian municipalities. The majority of such agreements seek to foster the exchange of best practices in urban public policymaking. One example of municipal paradiplomatic activity that is institutionally steered within regional integration processes is the Consultation Forum of Municipalities, Federate-States, Provinces and Departments of Mercosur, whose activities started in 2007.

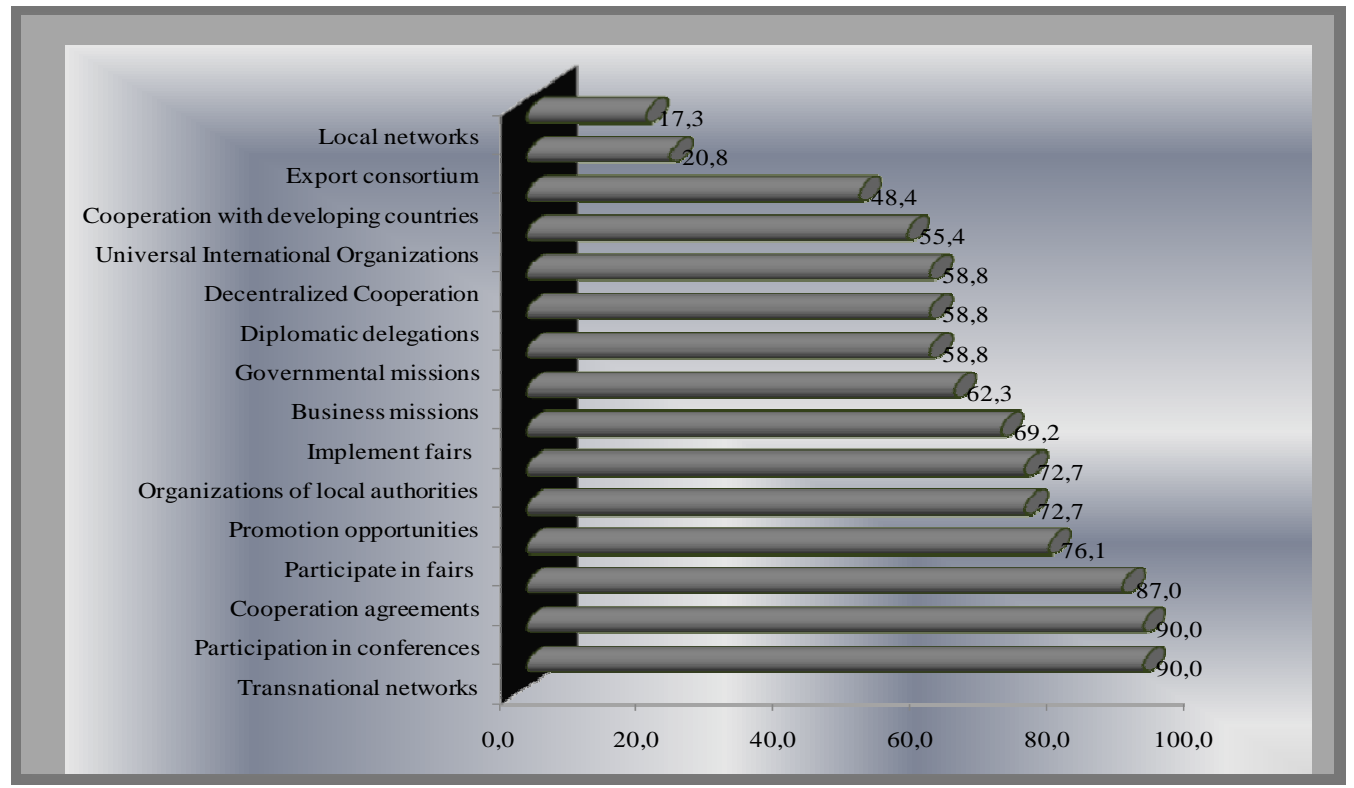

Figure 5. International actions implemented by municipalities having a formal IR structure (29 respondents).

The principal benefits brought about by municipal paradiplomacy, and reaffirmed by mayors and local managers in our survey, include technical cooperation (27\%), international visibility and prestige $(18 \%)$, as well as national recognition (18\%). Other secondary benefits mentioned are investments (13\%), local awareness to the relevance of international affairs (11\%) and exchange of experiences (13\%). 
Table 4

Cities with which the 29 municipalities having a formal IR structure have signed twin-city agreements

\begin{tabular}{lll}
\hline \multicolumn{1}{c}{ EUROPE } & \multicolumn{1}{c}{ NORTH-AMERICA } & \multicolumn{1}{c}{ ASIA } \\
$\begin{array}{l}\text { • Italy, Portugal, France, Spain, } \\
\text { Germany }\end{array}$ & $\begin{array}{l}\text { • USA, Canada, and secondarily } \\
\text { Lexico }\end{array}$ & \multicolumn{1}{c}{ C China and Japan } \\
$\begin{array}{l}\text { - Argentina, Chile, and secondarily } \\
\text { Uruguay, Paraguay and Bolivia }\end{array}$ & • South Africa and Mali & FRANCE IN THE CARIBBEAN \\
\hline
\end{tabular}

\section{The International Mobilization of Brazilian Cities: a "Soft-Border Approach" in a Changing World Political Order?}

This survey shows that there has doubtlessly been increased international mobilization by Brazilian municipalities since the early nineties, irrespective of the fact that some mayors may opt for a more or less institutionalized format of their internationalization strategies. There are, however, clear-cut variations as to motivations, relevance, perceived shortcomings and geographical focus of on-going or planned partnerships. To a certain extent, domestic regional asymmetries and economic development indicators explain the degree of intensity and professionalization of the municipal deployment of transnational actions. Municipalities express a form of political agency that reveals a political will for greater recognition in the international scenario, but also some institutional autonomy in a global context that is more complex and pluralistic. The role (vision, understanding, experience) of the mayor is also a key institutional factor in explaining why municipal paradiplomacy emerges and/or develops more significantly, since he/she is autonomous in decision-making for submitting (or not) the setting up of innovative governance structures designed for that purpose to the local assembly.

Furthermore, this survey illustrates that cities are playing key roles in providing some connecting points (economic, technological, information) to their citizens, economic operators and local organizations. Regional and global networks of cities offer subnational entities greater opportunities for the development of new institutional frameworks and partnerships concerning longterm benefits in terms of local development, particularly through infrastructural programs (water works, waste management, urban planning, participatory budgeting and environmental zoning) and economic or cultural activities (tourism, technical cooperation, exchange programs). Networks such as Mercociudades, Cities Alliance and the Forum of Local Authorities may support power-sharing arrangements at subnational and transnational levels working on traditional public functions that are considered crucial to the promotion of local development and economic growth and the attraction of direct foreign investment. Intergovernmental organizations (development banks, the European Union and UN agencies) may also play a key role in these institutional arrangements.

Moreover, our study demonstrates that the spatial dimension of the world political order and its structures is changing. Subnational entities share the same transnational zone, use technological resources and call into question the monopoly of the nation-state in world politics. Municipal paradiplomatic strategies are virtually re-territorializing public actions through a territorial continuum running from local to national then to global, thereby contributing to the emergence of a transnational social space. It is important to point out that cities span locally and globally, both geographically and politically: for instance, they may at the same time launch a local action related to urban planning and an international cooperative network connected with environmental management. Through municipal paradiplomacy, cities are important scales of action and networking in the politics and economics of globalization. 
Scale here describes a physical and a social organization of territories, but also helps to explain current transformations of global political processes. It is through inter alia a scale analysis that we can answer the question: where does international politics and international management take place? Geographical scales simultaneously integrate physical, economic, cultural and social features of political interaction, and must be understood as complex and socially contested territorial scaffoldings towards which multiple forms of territorial organization converge (Brenner, 1998). Based on this understanding of scale, the territorial state is itself a form of multi-scale territorial capitalist organization that encompasses national, subnational and supranational scales. The same applies to transnational social movements, networks of cities and economic flows that frame both materially and symbolically sociabilities, economic and political relationships worldwide. That is why trying to understand contemporary world politics does not only imply describing the role of individual States and transnational actors and the nature of the international system, but it supposes the analysis of the physical and social framing of political interactions and conflicts established among individuals, States, cities, firms, organizations and the international order in particular scales of action (Sjoberg, 2008).

The case of Brazilian cities, where more than $75 \%$ of the national population live, is an extremely relevant scale of analysis for understanding world politics and international management nowadays. Through this study we need to acknowledge that Brazilian cities have an improved participation in international organizations (particularly since Istanbul Habitat-II Conference ${ }^{(3)}$ ) and transnational networks that increasingly bear upon interests and agendas of the policy makers of central governments. These formal and informal institutional schemes develop out of a common interest in providing public goods more efficiently, and implementing regional and cross-border economic, cultural and social projects.

Nevertheless, the Brazilian cities surveyed do not call ethno-national belonging into question. Emancipation exists, but only partially, and not irrespective of the federative pact and the contradictory (but sustained) role of the nation-state in Brazil. Our case shows, in a different manner from what empirical evidence from Canada or Spain reveals, that allegiances to polities through which citizens enjoy public goods and participate to a greater or lesser degree in public life require long shared histories or deep cultural ties (Aldecoa \& Keating, 2000; Paquin, 2004). Based on the examples of Spanish comunidades autónomas, Cornago (2010) demonstrates that the paradiplomacy of sub-state entities enables the diplomatic system to operate in an increasingly complex environment while simultaneously affirming its own hierarchical structure; however, the limits of what he calls the normalization process ${ }^{(4)}$ are much wider in the Brazilian case. Brazilian cities, through paradiplomatic activities, do not put security policies and macro political institutions of the nationstate at risk. Municipal paradiplomacy is not a threat, rather it should be embraced as an instrument in the process of managing and attempting to provide solutions to situations that might otherwise be unresolved by central government.

It is true that the diplomatic system should respond more effectively to the growing international activism of Brazilian municipalities, the role of which calls into question issues of border crossing, boundary setting and decision-making. As Mostov (2008) asserts, national sovereignty has to do with jurisdiction over territory and boundaries of the nation-state and the right to make laws, including the right to determine who is a citizen and who enters the country. This aspect of sovereignty (external sovereignty) is the basis for membership in international organizations and participation in the interstate system. Recognition of the sovereignty of a nation-state implies acknowledgement of the inviolability of its borders and its final authority over what goes on within those borders. This notion of external sovereignty (as a relationship with other States and international institutions) presumes a notion of hard borders. Unregulated or unauthorized border crossings would constitute violations of sovereignty (Mostov, 2008). This is why movements that can avoid regulation or, by their very nature, are immune to or beyond authorization (pollution, capital flows, electronic messages, transnational social movements, city networks and subnational paradiplomacy) call into question the monopoly of this classical category in explaining today's world politics. 
An alternative to this hard-core version of national sovereignty would be to soften the sense of boundaries of the State and radically rethink the very notions of sovereignty, self-determination and citizenship rights in order to shift the focus from external sovereignty to a relational notion of internal sovereignty. This would involve focusing on the relationships of power in the processes of social choice and rearticulating the spaces and scales within which democratic relationships can be built. With this shift, the law-making function of sovereignty comes to the forefront, and the enabling conditions (resources, rights, and obligations) could function as means for opening rather than closing political boundaries (Mostov, 2008). Of course this should apply in all senses, from South to North, North to South, from East to West and West to East worldwide.

\section{Concluding Remarks}

The survey of seventy-two municipalities in Brazil conducted between 2007 and 2008 shows that Brazilian local authorities play key roles in connecting citizens, economies, cultures and organizations, particularly through regional and transnational networks (Sassen, 2006). They produce important innovations that contribute to the pluralization of global life. The survey also shows an incremented complexification of today's world political order, in which the classical and Realist in/out divisions tend not to make complete sense of the empirical and historical reality. The notion of an unconditioned sovereignty built under an imaginary of modernity, as well as our ontologies in crafting theoretical frameworks to understand world reality, require profound revision. Realism is not a problem because it insists on the role of the nation-state in world affairs, but mostly because it does not develop in a consistent fashion a theory of what constitutes the State, how it is built and what its contradictions might be (Walker, 1993). The philosophy of history behind realism tends to impose an ontological conception of what the authority of the state means (its sovereignty, its capacity to control national territory in absolute terms), and this conception would be a sufficient condition for understanding and explaining past, present and future world orders. This conception would not be one particular feature of some forms of international life and world politics.

As Inayatullah and Blaney (2004) report, international relations are a world, but are also various worlds in which one can find spatial and temporal contact zones where subjects, organizations, actors and processes once separated by geography and history can now engage in dialog and enter into conflict in today's globalized political order. This implies a rupture with an "empire of uniformity" (Inayatullah \& Blaney, 2004, p. 187). From this process of opening/closing borders and territories results a contemporary world space no longer invested and occupied exclusively by nation-states, but reconfigured into a truly "plurilateral structure” (Cerny, 1995, p. 595).

But changes are not only structural or exclusively in terms of philosophical conception and historical movement. They also occur at the level of political agency, since our surveyed municipalities reveal a political will for greater recognition in the international domain, and to a lesser extent some form of institutional autonomy in a more complex and pluralistic global context. Therefore, changes can be applied at the level of diplomatic instruments: from classical nation-state diplomacy to a multi-level diplomacy (Hocking, 2004), we should today understand and anticipate the need for mechanisms of linkage and institutional bodies to guide the coordination and cooperation between federal, federate-state and municipal levels of governance. This coordination is of great relevance when it comes to building and developing all kinds of international strategies and actions within the Brazilian federation.

Nevertheless, the empirical evidence from our study also demonstrates that Brazilian cities, through their diversified paradiplomatic activities, do not challenge either national foreign policy structures or the political identity of the nation-state. It raises some critical issues related to the multiple ways through which municipal paradiplomacy is developed across Brazil, but mainly concerning organizational management and decision-making procedures. Analytically it proves that cities' soft-border approach is deployed in association with a particular and pragmatic strategy of 
local international management, which offers greater opportunities for local organizations to span transnationally, not always and necessarily with the direct support and control of the nation-state. Local international management implies the development of new municipal organizational strategies and local/global governance partnerships, particularly in terms of infrastructural programs, technical assistance and cooperation for development. Capacity-building and institutional-building at the local level play a key role in this process.

\title{
Received 15 January 2010; received in revised form 16 June 2010.
}

\section{Notes}

\begin{abstract}
${ }^{1}$ Mercociudades (or Mercocities) is a cooperation network composed of 181 cities from the member-states of Mercosur (Common Market of the South), the main objective of which is to increase the participation of cities in the regional integration process through the development and exchange of best practices in urban planning and social policies (for further details, see: http://www.mercociudades.org).

${ }^{2}$ The complete list of surveyed municipalities include: Americana, Aracaju, Belém, Belo Horizonte, Blumenau, Boa Vista, Camaçari, Campina Grande, Campinas, Campo Grande, Caxias, Chuí, Contagem, Corumbá, Cubatão, Cuiabá, Curitiba, Diadema, Duque de Caxias, Feira de Santana, Florianópolis, Fortaleza, Foz do Iguaçu, Goiânia, Gravataí, Guarulhos, Ipatinga, Itaqui, Itu, Jaboatão dos Guararapes, Jacareí, Jaguarão, João Pessoa, Joinville, Jundiaí, Londrina, Macapá, Maceió, Manaus, Maringá, Natal, Nova Iguaçu, Olinda, Osasco, Ouro Preto, Palmas, Ponta Porã, Porto Alegre, Porto Velho, Recife, Ribeirão Preto, Rio Branco, Rio de Janeiro, Rio Preto, Salvador, Santa Maria, Santana do Livramento, Santo André, Santos, São Bernardo do Campo, São Borja, São Caetano, São Gonçalo, São José do Rio Preto, São José dos Campos, São Luís, São Paulo, Sorocaba, Teresina, Uberlândia, Uruguaiana and Vitória.

3 The second United Nations Conference on Human Settlements (Habitat II, held in Istanbul from 3 to 14 June 1996, addressed two themes of equal global importance: adequate shelter for all and sustainable human settlements development in an urbanizing world. For detailed information on UN activities in this field, see http://www.unhabitat.org.

${ }^{4}$ Cornago (2010) says that "normalization simultaneously allows the flourishing of diplomatic innovation that growing pluralization of international life produces, while simultaneously affirming the hierarchical structure of the diplomatic system". He defines normalization as "a mode of control that recognizes an otherwise deviant practice as valid, while the limits of these practices are fixed and carefully monitored” (p. 14).
\end{abstract}

\section{References}

Aldecoa, F., \& Keating, M. (2000). Paradiplomacia: las relaciones internacionales de las regiones. Madrid: Marcial Pons.

Associação Brasileira de Organizações Não Governamentais. (2007). Diplomacia não-governamental. São Paulo: ABONG/Coordination Sud.

Baylis, J., \& Smith, S. (2001). The globalization of world politics. Oxford: Oxford University Press.

Beck, U. (2003). Pouvoir et contre-pouvoir à l'ère de la mondialisation. Paris: Flammarion.

Benhabib, S. (2006). Democratic iterations: the local, the national and the global. In S. Benhabib (Ed.), Another Cosmopolitanism (pp. 47-97). Oxford: Oxford University Press.

Brenner, N. (1998). Between fixity and motion: accumulation, territorial organization and the historical geography of spatial scales. Environment and Planning D: Society and Space, 16(4), 459-481. doi: 10.1068/d160459

Cerny, P. (1995). Globalization and the logic of collective action. International Organization, 49(4), 595-625. doi: 10.1017/S0020818300028459 
Cornago, N. (2010). On the normalization of sub-state diplomacy. The Hague Journal of Diplomacy, 5(1/2), 11-36. doi: 10.1163/187119110X12574289877281

Dollfus, O. (1997). La mondialisation [Collection La Bibliothèque de Sciences-Po]. Paris: Presses de Sciences-Po.

Duchacek, I. D. (1990). Perforated sovereignties: toward a typology of new actors in international relations. In H. J. Michelmann \& P. Soldatos (Eds.), Federalism and international relations: the role of subnational units (pp. 1-33). New York: Oxford University Press.

Fiori, J. L. (2005). O poder americano. Petrópolis: Editora Vozes.

Hocking, B. (2004). Regionalismo: uma perspectiva das relações internacionais. In T. Vigevani, L. E. Wanderley, M. I. Barreto, \& M. P. Mariano (Orgs.), A dimensão subnacional e as relações internacionais (pp. 77-107). São Paulo: Editora PUC/UNESP/CEDEC/FAPESP.

Ianni, O. (2002). Teorias da globalização. São Paulo: Civilização Brasileira.

Inayatullah, N., \& Blaney, D. L. (2004). International relations and the problem of difference. New York: Routledge.

Lachapelle, G., \& Paquin, S. (2005). Mastering globalization: new sub-states’ governance and strategies. London: Routledge.

Lecours, A. (2008). Political issues of paradiplomacy: lessons from the developed world [Discussion Paper $N^{\mathrm{o}}$ 113]. Netherlands Institute of International Relations 'Clingendael', The Hague, The Netherlands.

Milani, C. R. S., \& Laniado, R. N. (2007). Transnational social movements and the globalization agenda: a methodological approach based on the analysis of the world social forum. Brazilian Political Science Review, 1(2), 10-39.

Mostov, J. (2008). Soft borders, rethinking sovereignty and democracy. London: Palgrave Macmillan.

Nunes, C. J. S. da (2005). A paradiplomacia no Brasil: o caso do Rio Grande do Sul. Unpublished Master's degree dissertation, Federal University of Rio Grande do Sul, Porto Alegre, RS, Brazil.

Paquin, S. (2004). Paradiplomatie et relations internationales: théorie des stratégies internationales des régions face à la mondialisation. Bruxelles: Presses Interuniversitaires Européennes.

Ribeiro, M. C. T. (2008). Globalização e novos atores: as cidades brasileiras e o desenvolvimento da paradiplomacia. Unpublished Master's degree dissertation, Federal University of Bahia, Salvador, BA, Brazil.

Rodrigues, G. M. A. (2004). Política externa federativa: análise de ações internacionais de Estados e municípios brasileiros. Unpublished PhD's degree dissertation, Brazilian Center of International Relations, São Paulo, SP, Brazil.

Salomón, M. (2007, July). La acción exterior de los gobiernos subnacionales y el análisis de políticas exteriores. Anais Encontro Nacional da Associação Brasileira de Relações Internacionais, Brasília, DF, Brazil, 1.

Santos, M., Souza, M. A. de, Scarlato, F. C., \& Arroyo, M. (1994). Fim de século e globalização. São Paulo: Hucitec-Anpur.

Sassen, S. (2006). Cities in a world economy. Thousand Oaks: Pine Forge Press.

Sjoberg, L. (2008). Scaling IR theory: geography's contribution to where IR takes place. International Studies Review, 10(3), 472-500. doi: 10.1111/j.1468-2486.2008.00801.x 
Smouts, M.-C. (2004). As novas relações internacionais: práticas e teorias. Brasília: Editora da UnB.

Soldatos, P. (1990). An explanatory framework for the study of federated states as foreign-policy actors. In H. J. Michelmann \& P. Soldatos (pp. 34-53), Federalism and international relations: the role of subnational units. New York: Press Oxford University Press.

Therborn, G. (2000). Globalizations: dimensions, historical waves, regional effects, normative governance. International Sociology, 15(2), 151-179. doi: 10.1177/0268580900015002002

Touraine, A. (2005). Un nouveau paradigme, pour comprendre le monde aujourd'hui. Paris: Fayard.

Troyjo, M. P. (2005). Manifesto da diplomacia empresarial e outros escritos. São Paulo: Aduaneiras.

Velasco e Cruz, S. C. (2004). Globalização, democracia e ordem internacional. São Paulo: Editora da UNESP e Campinas: Editora da UNICAMP.

Vigevani, T. (Org.). (2006). Gestão pública e inserção internacional das cidades [Relatório Científico de Pesquisa, Vol. 2], São Paulo: CEDEC, PUC-SP, FGV-SP, UNESP.

Walker, R. B. J. (1993). Inside/outside: international relations as political theory. Cambridge: Cambridge University Press. 